\title{
Carsten Rietmann*
}

\section{Hidden Champions and their integration in rural regional innovation systems: Insights from Germany}

https://doi.org/10.1515/zfw-2021-0024

Received: June 11, 2021; accepted October 29, 2021

Abstract: This article studies the integration of Hidden Champions - little-known highly innovative global market leaders - in rural regional innovation systems (RIS) in Germany. These firms are analyzed in relation to their integration into a RIS framework, which differentiates two subsystems: knowledge generation and diffusion, and knowledge application and exploitation. The relevance of firm-internal and firm-external regional influencing factors on rural RIS integration is examined. The article proposes that Hidden Champions are weakly integrated in RIS due to their international sales focus and high technological specialization. To test this premise, 57 expert interviews with Hidden Champions and regional actors were conducted. It was found that key influences for RIS integration of this firm type are ownership structure, firm size, organizational status, location economies, and urbanization economies. Family businesses are on average more integrated than other firm types, but vary significantly in their integration.

Keywords: Family-owned firms; Hidden Champions; qualitative analysis; regional innovation systems; rural areas

\section{Introduction}

Globalization and digitalization are frequently contrasted with the local integration of firms, particularly for innovation processes. These forces enable enterprises to source knowledge and engage in innovation across greater distances, 'replacing spatial proximity with cloud-based connectivity' (The Atlantic 2021). Simultaneously, research also emphasizes the importance of localized innovation systems, whose institutionally-embedded complex inno-

\footnotetext{
*Korrespondierender Autor: Carsten Rietmann, Institute of Economic and Cultural Geography, Leibniz University Hannover, Schneiderberg 50, 30167 Hannover, Germany; E-Mail: rietmann@wigeo.uni-hannover.de; ORCID ID: https://orcid.org/0000-0002-9738-6768
}

vation processes highlight the ongoing importance of the regional aspect (Gertler et al. 2000).

These phenomena are highly relevant for Hidden Champions. These little-known small and medium-sized firms are highly innovative and possess global or continental market leadership in their product niches (Simon 2018). On the one hand, they are highly relevant for their home regions through economic effects, such as business taxes, employment, human capital development, corporate regional engagement, and additional intangible effects. On the other hand, these firms have disproportionately high export ratios and extensive international sales networks. In addition, Hidden Champions produce highly specialized products and hence require very specific fields of knowledge in their R\&D activities (Rammer \& Spielkamp 2019). Furthermore, their headquarters are frequently located outside of industrial agglomerations: in Germany, two-thirds of Hidden Champions are located in rural areas (Schenkenhofer 2020). Rural regions and firms located in this geographical context face special conditions, such as external resource constraints (Eder \& Trippl 2019). These special conditions manifest themselves in thin RIS and the absence of clusters (Tödtling \& Trippl 2005). As a consequence of these aspects, this paper proposes that the integration of Hidden Champions in rural regional innovation systems (RIS) can be assumed to be relatively low.

This article examines the integration of Hidden Champions in rural RIS in Germany and its firm-internal and firm-external regional influencing factors. Firm-internal and firm-external characteristics are considered important dimensions in economic geography for investigating RIS integration and the regional embeddedness of firms (Autio et al. 2014). The provision of additional insight into both perspectives is a main contribution of this paper to this debate. Firstly, firm-internal characteristics such as ownership structure and organizational status are major determinants of integration in RIS. Two-thirds of these firms in Germany are family-owned firms (Venohr \& Meyer 2007) - a firm type linked to long-term orientation and distinct forms of spatial familiness (Basco \& Suwala 2020). Family-owned firms in general are crucial for the prosperity and strength of local and regional economies, among 
other factors, due to significant contributions to regional employment, the tax base, and vocational training (Baù et al. 2019, Lenz \& Glückler 2021). Nevertheless, RIS integration of family-owned firms has rarely been examined - in defiance of the firm type's capacity to alter regional institutions (Basco 2015).

Secondly, in terms of firm-external regional characteristics, rural regions are an important spatial category for Hidden Champions, as stated above. Most research, however, focuses on innovation in agglomeration areas (Isaksen \& Karlsen 2016), emphasizing the notion of metropolitan innovation systems (Bathelt \& Henn 2017). As a consequence, there is scant research concerning the integration of firms in rural RIS. Recent contributions have attempted to close this research gap (Eder 2019; Fritsch \& Wyrwich 2021). In such rare instances, studies are overwhelmingly concentrated on small-scale entrepreneurship, examining firms catering to local markets (Greenberg et al. 2018), other niches of entrepreneurship, or local linkages related to FDI-induced plants of multi-national enterprises (MNE) (Meyer et al. 2011) - in the latter case focusing on firm locations solely with production capacities and no other corporate functions.

As a consequence, the following research question is posed: What influences the integration of Hidden Champions in rural regional innovation systems? As indicated above, the proposition here is that these firms are not strongly integrated in RIS due to their international sales focus, specialized technology, and rural location. The article contributes to the literature on RIS by providing evidence (a) for a firm type thus far not analyzed in terms of RIS integration and (b) for a regional type (rural areas) thus far not strongly associated with highly innovative firms and under-researched regarding RIS. Moreover, this paper responds to the call for an increased cross-fertilization between economic geography and family business studies (Basco \& Suwala 2020; Basco et al. 2021).

A qualitative research design with semi-structured expert interviews is employed (Meuser \& Nagel 2009). In total, 57 interviews in four rural German regions with management representatives of Hidden Champions and other regional actors were conducted. The study is structured as follows. Section 2 outlines the current state of research concerning the RIS integration of Hidden Champions and family-owned firms and develops the research question. Section 3 describes the qualitative methodology employed for this study. Section 4 presents the results in terms of a framework of RIS integration of Hidden Champions and its influencing factors. Section 5 concludes with a summary and discussion.

\section{State of research and theoretical framework}

Multiple streams of literature with relevance for this study were identified: Integration in RIS, firm-internal and firm-external regional influences on integration in RIS, and RIS integration of Hidden Champions. Based on an overview of these streams, the research question for this article will be subsequently developed.

\section{Integration in regional innovation systems (RIS)}

The RIS approach is a useful analytical device for considering the spatial aspects of innovation and for highlighting the importance of local networks (Asheim \& Isaksen 1997). In combination with other territorial innovation models (TIM) such as learning regions or clusters, RIS have attracted increasing attention and popularity (Moulaert \& Sekia 2003; Bathelt \& Henn 2017). The concept is based on the understanding of innovation as a systemic process that thrives on concentrated economic activity in an area that is spatially confined (Doloreux \& Porto Gomez 2017). In this regard, the underlying reasoning is that innovative activity of organizations not only depends on the knowledge embedded in the organization itself, but additionally on the interaction and knowledge exchange of various regional organizations and their institutional environment (Cooke et al. 2004).

Following Autio (1998), a RIS entails two subsystems: knowledge generation and diffusion, and knowledge application and exploitation. While the subsystem of knowledge generation and diffusion mainly consists of public organizations (e.g. research institutions, universities, regional development agencies) and the subsystem of knowledge application and exploitation of firms (e. g. suppliers, customers, competitors), several overlaps of these organizational types in both subsystems can be observed (Cooke 2002). For instance, these overlaps apply to knowledge application and exploitation activities of universities of applied science. This paper employs a firm-centric perspective on RIS, examining the integration of a single firm at its main location in these RIS subsystems (Kalantaridis \& Bika 2011). It follows a line of research on RIS integration of specific firms and organizations such as large local R\&D-intensive firms (Agrawal \& Cockburn 2003). While most research on RIS has focused on the ways in which regions foster favorable conditions for innovation (Doloreux \& Porto Gomez 2017), this firm-centric approach 
is particularly applicable for the research question of this study. In terms of regional characteristics, research has mainly focused on agglomeration areas and particularly on disproportionately successful examples, implying problematic generalization (Bathelt \& Henn 2017). Notable exceptions are Tödtling \& Trippl's (2005) portrayal of thin rural RIS and Doloreux' (2003) case study of peripheral Québec.

Integration in RIS is important for firms due to its relevance for business performance (Davidsson et al. 2006), regional sales levels (Cooke et al.2007), international competitiveness and international R\&D alliances (Al-Laham \& Souitaris 2008), effective innovation through network capital (Huggins \& Thompson 2015), and its contribution to regional development (Bürcher 2017). RIS integration further prioritizes linkages with regional contractors and customers, and eases local accessibility of both tangible and intangible assets (Baù et al. 2019). In particular, RIS integration can be particularly beneficial for firms in their early stages of development (Keeble et al. 1998). A key rationale for RIS integration is based on the availability, accessibility, and spillover of localized complex, tacit, and codified knowledge (Gertler 2003). Here, geographical, relational, and cognitive proximity are intertwined and condition each other (Capello 2001). Social capital and mutual trust has been shown as underlying several of these rationales and outcomes (Cooke et al. 2005). However, it needs to be noted that evidence on the relationship of business and innovation performance and RIS integration is ambiguous and varies according to sector. For Swedish machinery producers, for instance, "there is a negative correlation between localized technological relations and firm performance" (Larsson \& Malmberg 1999).

Moreover, another branch of the RIS literature has focused on the interplay of RIS integration and globalization for transnational corporations. It uses the notion of strategic coupling to emphasize the need to complement intra-regional corporate processes (MacKinnon 2012). Research on global production networks has highlighted the globalization of regional development, viewing the region as porous in terms of trans-regional network connections of economic actors (Coe et al. 2004). These parallel global and local linkages (Asheim \& Isaksen 2002) are of specific relevance for regions with thin RIS and resource constraints, such as rural areas, implying the need for compensation strategies such as trans-regional knowledge sourcing (Eder \& Trippl 2019; Herb \& Neiberger 2021). This interplay could prove to be particularly important for Hidden Champions, considering their internationalized sales networks and requirements for specialized knowledge.
Some of the studies portrayed explicitly focus on integration in terms of RIS, but occasionally employ related approaches - predominantly associated with Granovetter's (1973) understanding of embeddedness or by attempting to measure the degree of local integration and embeddedness of firms through firms' shares of local sales and sourcing (e.g., Halaszovich \& Lundan 2016). The next section will further outline and describe firm-internal and firm-external regional influences on firm integration in RIS.

\section{Firm-internal and firm-external regional influences on firm integration in RIS}

Research has shown that RIS integration of firms is influenced by firm-internal and firm-external dimensions (Kalantaridis \& Bika 2006). Table 1 provides an overview of relevant influencing dimensions.

Firm-internally, ownership structure, firm size, organizational status, market position and industry, innovative capacity and technological focus, and firm leadership/ management characteristics have been shown to be influential for RIS integration. Regarding ownership structure, family-owned firms are distinct in their long-term orientation (Lumpkin \& Brigham 2011), home-region focus and regional identity, secrecy and a sense of local stewardship (Banalieva \& Eddleston 2011), spatial loyalty (Pallares-Barbera et al. 2004), and relevance of non-economic goals and bounded rationality (Chrisman et al. 2014). Family-owned firms are more embedded in their home regions than non-family-owned firms (Bird \& Wennberg 2014), which is frequently attributed to increased local social capital (Arregle et al. 2007). The latter enables family-owned firm leadership to utilize localized resources, contributing to business growth and performance. As a consequence, localized social capital is understood as a compensation strategy against resource constraints in rural areas. However, family-owned firms are particularly heterogeneous regarding their strategic and innovative actions due to stronger relevance of managerial agency (Miller \& Le Breton-Miller 2020).

Firm-external regional dimensions are further important influencing factors for RIS integration and include location (or milieu) economies, urbanization economies, the degree of peripherality of firm location, and technology and innovation policy. Regional resource availability plays a significant role and varies between urban and rural regions (Eder \& Trippl 2019). Here, the extent of RIS integration can be understood as either an exploitation or a compensation strategy (Eder \& Trippl 2019). Rural areas 
offer distinct and frequently challenging conditions for innovation (Virkkala 2007). Scholars have recognized the specificity of RIS in rural areas (Doloreux 2003; Doloreux \& Dionne 2008; Kalantaridis \& Bika 2011; Yin et al. 2019). The characteristics of rural RIS are related to resource constraints, institutionally-thin RIS, limited knowledge externalities and spillovers, weakly developed or missing clusters, dominance of SMEs, low levels of R\&D and product innovation, few research institutions and high-profile universities, low to medium-level qualifications, and a focus on the extraction of raw materials (Tödtling \& Trippl 2005). In a case study of SMEs in rural Québec, Doloreux (2003) identifies the availability of skilled labor, trust between regional actors, and supplier proximity as the most important firm-external factors determining RIS integration.

Table 1: Selection of firm-internal and firm-external regional influences on RIS integration

\begin{tabular}{|c|c|}
\hline Influencing factors & State of the literature: Implications and mechanisms \\
\hline \multicolumn{2}{|l|}{ Firm-internal characteristics } \\
\hline Ownership structure & $\begin{array}{l}\text { RIS integration is influenced by ownership structure, with family businesses being particularly integrated (Bird } \\
\& \text { Wennberg 2014; Baù et al. 2019), induced by high regional social capital in comparison with other owner- } \\
\text { ship and leadership types (Arregle et al. 2007) }\end{array}$ \\
\hline Firm size & $\begin{array}{l}\text { Through abundant internal resources, larger firms have the capacity to act as focal or anchor firms in RIS or are } \\
\text { alternatively able to remain isolated due to self-sufficiency, vertical integration or greater ability to maintain } \\
\text { extra-regional linkages (Christopherson \& Clark 2007; Munari et al. 2012) }\end{array}$ \\
\hline $\begin{array}{l}\text { Organizational status } \\
\text { (e.g. single-location firm, } \\
\text { headquarters, branch, } \\
\text { subsidiary, location of } \\
\text { R\&D) }\end{array}$ & $\begin{array}{l}\text { Headquarters location is related to regionally embedded management (Doloreux \& Dionne 2008); co-location } \\
\text { of R\&D functions increases local RIS integration through linkages to educational and research institutions and } \\
\text { to collaborators (Branstetter 2006); FDI-linked production plants of MNEs/TNCs lack RIS integration due to } \\
\text { reduced necessity for plant-based knowledge generation and diffusion (Meyer et al. 2011) }\end{array}$ \\
\hline $\begin{array}{l}\text { Market position and } \\
\text { industry }\end{array}$ & $\begin{array}{l}\text { RIS integration differs according to industry and market (Watts et al. 2006); firms catering to local markets are } \\
\text { strongly integrated in RIS due to the regional location of customers, and frequently suppliers and contractors } \\
\text { as well (Greenberg et al. 2018), while manufacturing firms with high export shares are least integrated due to } \\
\text { extra-regional customer bases and specialized supplier requirements (Arndt \& Sternberg 2001) }\end{array}$ \\
\hline $\begin{array}{l}\text { Innovative capacity and } \\
\text { technological focus }\end{array}$ & $\begin{array}{l}\text { High innovative capacity is associated with limited spillovers due to lacking cognitive proximity to regional } \\
\text { knowledge base and the absorptive capacity of RIS actors (Asheim \& Coenen 2005, Capello 2014; Reidolf } \\
\text { 2016); also shown for FDI in transition economies (Suwala \& Micek 2018) }\end{array}$ \\
\hline $\begin{array}{l}\text { Firm leadership/manage- } \\
\text { ment }\end{array}$ & $\begin{array}{l}\text { Owner-managed firms utilize local social capital more effectively due to overlaps of personal and corporate } \\
\text { social capital (Arregle et al. 2007); personal origin and current residential location of ownership and leader- } \\
\text { ship are additional influencing dimensions for RIS }\end{array}$ \\
\hline \multicolumn{2}{|c|}{ Firm-external regional characteristics } \\
\hline $\begin{array}{l}\text { Location (or milieu) } \\
\text { economies }\end{array}$ & $\begin{array}{l}\text { Geographical proximity to customers, suppliers, contractors, competitors, and R\&D collaborators positively } \\
\text { influences RIS integration (Doloreux 2003; Capello 2020) }\end{array}$ \\
\hline Urbanization economies & $\begin{array}{l}\text { Availability of relevant regional resources for firms, such as a qualified labor force, physical infrastructure, } \\
\text { and research institutions induces and conditions compensation and exploitation strategies for RIS integra- } \\
\text { tion (Doloreux 2003; Eder \& Trippl 2019); rural areas offer a specific RIS constitution with organizational and } \\
\text { institutional thinness, hence necessitating extra-regional innovation linkages or internalization of capacities } \\
\text { (Tödtling \& Trippl 2005; Virkkala 2007) }\end{array}$ \\
\hline $\begin{array}{l}\text { Degree of peripherality of } \\
\text { firm location }\end{array}$ & $\begin{array}{l}\text { The degree of peripherality of a firm location is linked to the distance to agglomerations and to regional } \\
\text { density and thickness of RIS, with greater peripherality complicating and aggravating knowledge transmission } \\
\text { across distances, regional resource availability, and physical proximity between regional actors (Polèse \& } \\
\text { Shearmur 2006; Eder 2019) }\end{array}$ \\
\hline $\begin{array}{l}\text { Technology and innova- } \\
\text { tion policy }\end{array}$ & $\begin{array}{l}\text { Existing structures, processes, and incentives for intra-regional R\&D cooperation facilitate and strengthen RIS } \\
\text { integration, particularly in rural areas (Sternberg \& Arndt 2001) }\end{array}$ \\
\hline
\end{tabular}

Source: Own elaboration. 
While the RIS integration of firm types such as family-owned firms (Basco et al. 2021) and multi-national enterprises (MNE) (Meyer et al. 2011) has been investigated, there is a void for Hidden Champions, potentially due to the firm characteristic of hiddenness. Most related research focuses on other firm types requiring less specialized knowledge and related resources such as firms with largely local markets (Greenberg et al. 2018). However, related research on RIS integration of SMEs and family businesses is relevant, as these firm types have many overlapping features with Hidden Champions and hence serve as a basis for approximation with regard to the research question. Moreover, scholars have analyzed the impact of family-owned firms in innovative industries on regional innovation activity (Block \& Spiegel 2011). Here, an assessment of the actual innovation output of these firms and of their fit with the definition of Hidden Champions (i.e. status of market leadership, etc.) has not been conducted before. Substantial research has investigated the local integration of MNE plants, focusing on foreign direct investment (FDI) in transition and emerging economies (Meyer et al. 2011, Suwala \& Micek 2018).

Additionally, there is scant research on rural RIS in contrast to the existence of ample studies on agglomerations. Furthermore, the integration of highly innovative firms in rural RIS has rarely been examined. In particular, RIS integration of innovative firms that are regionally dominant has not yet been studied in rural areas, but only in agglomerations and industrial districts, opening relevant research avenues for dominant firms in regions with a thin economic base (Munari et al. 2012).

\section{Hidden Champions and integration in RIS}

Research on rural RIS integration of Hidden Champions is rare, while this dimension of the firm-territory nexus has already been examined for other firm types such as family-owned firms (Basco \& Suwala 2020). The firm type has been studied widely, particularly in Germany and the broader German-speaking world (Simon 2018), with additional case studies for other countries (e.g. Lalić (2021) for several Eastern European and Asian countries and Voudouris et al. (2000) for Greece). Hidden Champions are considered the backbone of the German Mittelstand, which consists of export-oriented SMEs as an essential element for the competitiveness of the German economy (Simon 2009; Streeck 2009). As a result, their sustained corporate success in the digital age is regarded as essential for the overall economy's prosperity and especially for the structurally weak regions in which they are frequently located (Wittenstein 2020).

Through deliberate internationalization, Hidden Champions have a global focus (Simon 2009). On average, they possess an export share of $64 \%$ (compared to $39 \%$ for all German firms, Statistisches Landesamt Baden-Württemberg 2020) and feature a global network of sales offices (Rammer \& Spielkamp 2015). The corporate network of these firms hence consists of actors which are by definition international. Consequently, this paper proposes that firms of this type are not strongly integrated in rural RIS due to their international sales focus, high technological specialization, and rural location. Regarding the latter, the importance of the firm's location in determining fundamental conditions for corporate success, e. g. through the regional labor pool, available infrastructure, or regional policy, has been at the heart of economic geographical debates. Here, rural regions are an important spatial category for Hidden Champions being mostly located outside of industrial agglomerations. As indicated, the headquarters of two-thirds of them are located in rural areas (Schenkenhofer 2020), compared to $39 \%$ of all firms in Germany (Stiftung Familienunternehmen 2020). These firms have significant R\&D capacity and activity and employ innovation as a long-term business success strategy (Venohr \& Meyer 2007). They are typically mainly active in manufacturing sectors and focus their R\&D on incremental continuous process improvement (Rammer \& Spielkamp 2019). Hidden Champions further differ in their ownership structures, with two-thirds being family businesses, frequently in cross-generational family ownership (Venohr \& Meyer 2007; Rammer \& Spielkamp 2015).

Addressing the state of the literature and the research gap outlined above, the following research question is posed in this paper: What influences the integration of Hidden Champions in rural regional innovation systems? To answer this question, a RIS framework of two subsystems (knowledge generation and diffusion, and knowledge application and exploitation) is applied to systematically investigate the influences on the rural RIS integration of this firm type (Autio 1998; Cooke 2002). The framework and its dimensions are presented in Figure 1. The following section presents the findings along these identified factors for both subsystems. 


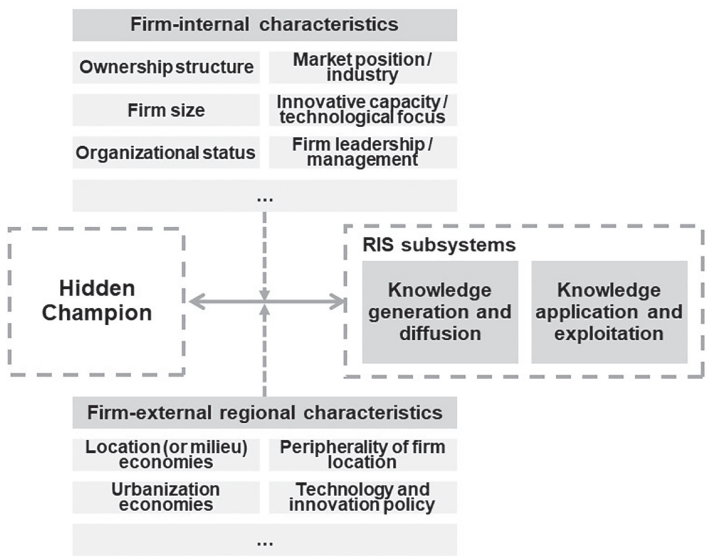

Figure 1: Influencing factors for rural RIS integration of Hidden Champions

Source: Own elaboration; RIS subsystems based on Autio (1998) and Cooke (2002).

\section{Methods: Data collection and analysis}

This study adopts a qualitative research approach to better understand how rural RIS integration of Hidden Champions is influenced. The method was deliberately chosen to investigate the complexities involved in RIS subsystem integration. Therefore, semi-structured interviews with Hidden Champions in rural areas in Germany as well as with actors from their regional context were conducted.

To gain a better understanding of regional characteristics, four rural regions with a large spectrum of demographic, economic and infrastructural indicators were selected, based on the empirical results for German regions by Küpper (2016) and Oberst et al. (2019). The Eurostat (2020) definition of rural regions was used. Two rural regions with a strong and two with a weak economic, demographic and infrastructural base were included. The regions selected were Central Hesse (north of Frankfurt to the northern district of Biedenkopf) and Leine-Weser in southern Lower Saxony in West Germany, as well as Lower and Upper Lusatia/Lausitz (Greater Dresden to the northern rural regions around the district of Oberspreewald-Lausitz) and the northeastern Harz foreland in the state of Saxony-Anhalt in East Germany.

To identify potentially relevant Hidden Champions, the Global Market Leader Index by Müller (2018) was used and enriched through interviews with Chambers of Industry and Commerce representatives. All firms were evaluated concerning their fit with Simon's (2009) definition of this firm type.
Between September 2020 and March 2021, 57 interviews were conducted with two actor types: Hidden Champion representatives and regional actors. The first group, representatives of Hidden Champions, consisted exclusively of members of the management. Employees in these leadership positions were targeted, as they are acquainted with the firm's history and regional context due to their long tenure typical for these firms (Venohr \& Meyer 2007) and have the authority to disclose details. One representative per firm was interviewed. In the sample of 28 Hidden Champions (response rate of $33 \%$, 84 firms were contacted), the share of firms active in manufacturing is $89 \%$, the remainder being firms that exclusively produce software. This distribution is proportionate to the general population of this firm type. The average turnover of 195 mill. $€$ per year is lower than the overall average of all Hidden Champions with 325 mill. $€$ (Simon 2018). The average share of exports of interviewed firms is $52 \%$ (compared with $64 \%$ for the general population; Rammer \& Spielkamp 2015) and the share of family-owned firms is $54 \%$ (compared with $66 \%$ for all Hidden Champions; ibid.). For the second group, 29 actors in the regional vicinity of these firms were interviewed to add insights into additional dimensions of RIS integration and to validate the perspectives of Hidden Champions (response rate of $83 \%, 35$ organizations were contacted). The regional distribution was equivalent for both interviewed groups. Actor types included mayors and representatives of regional development agencies as well as Chambers of Industry and Commerce. These actor types were targeted as they were both knowledgeable about the firms and their regional linkages, and were not subject to non-disclosure agreements, as potential collaborators from other regional firms or universities would have been. The interviews mainly concentrated on the interviewed firms, but also involved other regional Hidden Champions, if applicable. An overview of the regional characteristics of the sample is provided in Table 2 (for further details, see Tables A.1 and A.2 in the Online Appendix). Based on the theoretical point of departure described above, an interview guide was used in the interviews covering the RIS integration of these firms and structured by integration in the two subsystems and its elements (e.g. "How would you describe the relationship and interactions of your firm with regional universities?"). Due to the ongoing COVID-19 pandemic, all interviews were conducted remotely: most via video calls and the remainder via telephone. The interviews lasted $57 \mathrm{~min}$ on average and were audio-recorded and then transcribed. All statements by interviewees used in this article were translated into English. Confidentiality and anonymity were guaranteed to the interviewees to ensure openness. 
Table 2: Regional characteristics of sample

\begin{tabular}{|c|c|c|c|}
\hline & & Hidden Champions (HC) & Regional actors (RA) \\
\hline \multirow[t]{4}{*}{ Settlement size } & Large city (>100k population) & $0(0 \%)$ & $4(14 \%)$ \\
\hline & Medium-sized city (20k-100k population) & $7(25 \%)$ & $18(62 \%)$ \\
\hline & Small town (5k-20k population) & $13(46 \%)$ & $6(21 \%)$ \\
\hline & Village ( $<5 \mathrm{k}$ population) & $8(29 \%)$ & $1(3 \%)$ \\
\hline \multirow{5}{*}{$\begin{array}{l}\text { Regional classifi- } \\
\text { cation }\end{array}$} & Very rural / weak socio-economic conditions & $8(26 \%)$ & $7(24 \%)$ \\
\hline & Very rural / strong socio-economic conditions & $3(12 \%)$ & $4(14 \%)$ \\
\hline & Fairly rural / weak socio-economic conditions & $3(12 \%)$ & $3(10 \%)$ \\
\hline & Fairly rural / strong socio-economic conditions & $14(50 \%)$ & $12(42 \%)$ \\
\hline & Not rural & $0(\%)$ & $3(10 \%)$ \\
\hline \multirow{3}{*}{$\begin{array}{l}\text { Driving distance to } \\
\text { closest research } \\
\text { university }\end{array}$} & $<30$ minutes & $8(29 \%)$ & $\mathrm{n} / \mathrm{a}$ \\
\hline & $\geq 30 \&<60$ minutes & $15(53 \%)$ & $\mathrm{n} / \mathrm{a}$ \\
\hline & $\geq 60$ minutes & $5(18 \%)$ & $\mathrm{n} / \mathrm{a}$ \\
\hline Total & & 28 & 29 \\
\hline
\end{tabular}

Source: Own elaboration; regional classification based on Küpper (2016), based on nine indicators for socio-economic conditions, such as unemployment rates, median income, life expectancy, and housing vacancy rates; settlement size and driving distance to closest research university based on Statistisches Bundesamt (2021).

The interview transcripts were coded deductively along the structure of the RIS subsystems described above. In the following step, sub-dimensions of these subsystems (e.g. types of organizations, such as suppliers, customers, or research institutions) were used for deeper coding levels. The software $f 4$ was used for this purpose. One researcher coded the interviews after research assistants transcribed them. Subsequently, influencing factors for RIS integration were identified inductively and grouped as (a) firm-internal and (b) firm-external regional factors. This deductive-inductive approach (Gibbs 2018) offers a combination of advantages: while the inductive elements prevent biases and prejudices from the researchers responsible for interviewing, the deductive dimension enables an integration of these inductively identified factors based on a theoretical framework.

Additionally, the statements of the interviewees were selectively triangulated and validated with secondary data sources such as annual reports and firm websites (Graebner et al. 2012). These triangulations and validations focused on identifying and validating firm-internal and regional variables (e. g. firm size, existence of regional research institutions) as well as indicated linkages of Hidden Champions with other actors that are publicly visible, such as endowed professorships.

\section{Results}

The analysis of the interview material reveals the influence of firm-internal and firm-external dimensions for RIS integration. The effect of the specific influences will be described in the following section, differentiated according to the two RIS subsystems of knowledge generation and diffusion, and knowledge application and exploitation. Table A.3 in the Online Appendix displays how the firm-internal and firm-external regional influences on RIS integration of Hidden Champions were systematically identified in an inductive way, using the interview transcripts. Firm-internally, this pertains to ownership structure, firm size, and organizational status. Firm-externally, location (or milieu) economies and urbanization economies were identified as important. These factors will be further described in the following section.

\subsection{Firm-internal influences}

\section{Integration in RIS subsystems: Knowledge generation and diffusion}

Hidden Champions conduct business in specific product niches and are highly innovative, implying the need for 
specialized knowledge (Venohr \& Meyer 2007). Additionally, firms of this type are strongly internationalized in terms of sales networks (Rammer \& Spielkamp 2015). Hence, this paper hypothesizes that RIS integration concerning knowledge generation and diffusion, e.g. through linkages with higher education and research organizations, occurs based solely on specialization and cognitive proximity, and not necessarily on geographical proximity (Boschma \& Frenken 2011). However, the interview material reflects an ambiguous picture: all Hidden Champions surveyed have some form of connection with regional research and educational institutions, but differ in two important aspects.

Firstly, larger Hidden Champions and those that are not family-owned tend to be spatially flexible in their search for suitable cooperation with research institutions, while smaller firms of this type and family-owned firms deliberately search locally for partners and exploit their existing social capital and built-up trust (RA5). In particular, almost all Hidden Champions that are classified as family-owned firms are strongly interlinked with regional research institutions. The regional availability of research institutions such as research universities, universities of applied sciences, or other research institutes affects this pattern, as described in the next section on firm-external regional influences in the knowledge generation and diffusion subsystem (Doloreux 2003). Secondly, virtually all firms analyzed involve regional educational institutions such as universities and vocational schools for human capital-related purposes in the realm of knowledge diffusion. Often, these linkages possess a strategic element to attract, develop and retain qualified local labor and to transform these institutions according to particular corporate requirements (HC28, RA8). Forms of interaction include dual university programs, specialized apprenticeships, curricula customized to the technology foci of individual or groups of Hidden Champions, endowed professorships, supervised theses, internships hosted by these firms, and support for and sponsoring of youth IT competitions (HC10/17/20, RA8/12/28). These initiatives are reported as being particularly effective when the rural regional environment does not feature many other innovative or large firms, or both. Agency of Hidden Champion leadership also plays an important role in establishing and deepening relationships with research and educational institutions (Chrisman et al. 2014). In contrast to other firms, they value regional research institutions as very important. In this context, the representative of a regional economic development agency in Lusatia explains:
'Hidden Champions have this strong will to engage in technology transfer. We don't have to organize that. If we were involved, the transfer is by nature artificial. They already know pretty well what the local university can provide them with. [...] With micro-enterprises and other SME, it is not the case that they say: "I need a research ecosystem around me". Hidden Champions ask precisely for this, and they ask for it first.' (RA24)

Interview partners have highlighted how Hidden Champions with varying ownership structures and firm sizes differ in the degree of localization of research cooperation. Family-owned/operated firms are described as deliberately trying to engage local universities - if existing - in as many projects as possible and only search beyond the region if necessary. Additionally, alumni networks between research and educational institutions and the employee base of this firm type are relevant in terms of being acquainted with the respective institutions and having developed relationships with its members. The relatively small size and limited public awareness of Hidden Champions is pictured as a disadvantage for cooperation with large metropolitan universities and hence fosters regional collaboration with research institutions, since the intra-regional public awareness is considered markedly higher (Simon 2018). The following example from an economic development agency in Central Hesse illustrates this:

\begin{abstract}
'When Hidden Champions contact the big universities, they are one among many. Here [in our rural region], there is an existing relationship. The universities of applied sciences are more regionally oriented. Meanwhile, even Gießen University [as a research university] is doing the same. It now has a president who said: "Of course, a university has an international reputation. It has to have one. It needs the international connections in research, but we also have a regional responsibility."' (RA5)
\end{abstract}

In terms of relationships to policy organizations, Hidden Champions with larger firm sizes are reported as having a different spatial focus. They prioritize supra-regional linkages on national or state levels over local ones (HC14, RA9/27). The reasons given for this are strategic foci of regional economic development agencies that do not match the priorities and requirements of these firms, more adequate support programs at the supra-national level, and a general lack of entrepreneurial necessity to engage with local political stakeholders beyond matters such as building laws and digital infrastructure. The CTO of a powertrain technology Hidden Champion explained:

'We are simply too big for that. [...] If we want funding, we have to go to the state or the federal government.' (HC24)

Hidden Champions that are subsidiaries of larger corporations, and particularly of international ones, display lower 
integration with regional policy institutions - similar to findings on MNEs (Kramer \& Diez 2012). This also corresponds to the findings concerning linkages of these firms with regional research and educational institutions described above. The manager of a university-run technology transfer center exemplified this with the following statement:

'Yes, they [subsidiaries of larger corporations] may be Hidden Champions, but they are all externally determined. [...] We have hardly had any contact with most of the firms in the last five years or so, because headquarters are just far away in Brazil or Mexico.' (RA13)

\section{Integration in RIS subsystems: Knowledge application and exploitation}

As this firm type is active in product niches and has a global sales focus with high export ratios, there is no emphasis on regional sales reported in the interviews (cf. Rammer \& Spielkamp 2015). Regarding supplier networks, Hidden Champions as subsidiaries of larger corporations are portrayed as being less active in sourcing from regional suppliers. Interview partners frequently attribute this pattern to the influence of corporate purchasing units at the holding level. Particularly for private equity-owned firms and those that are subsidiaries of larger corporations, the notion of "islands" has been invoked to describe the lack of RIS integration in this subsystem. Interestingly, cases of ownership change provide insights into influencing factors of RIS integration: ownership transfer not only implies changes in the allocation of decision-making power, but also access to corporate $R \& D$ resources to substitute external knowledge sourcing (Bodner \& Capron 2018). The manager of the technology transfer center quoted above continues:

'Cooperation doesn't work anymore, because the headquarters that make the decisions are located far away across some ocean. And the management level with which you can get in touch is no longer on site. Only the production is located here. And that's a bit of a problem.' (RA13)

The firm size of Hidden Champions was negatively associated with integration in the RIS and its knowledge application and exploitation subsystem. A crucial distinction is to be made between the size of the firm's regional location and the overall firm size for firms with multiple locations. Here, important aspects in influencing RIS integration emphasized by interviewees are which corporate functions are located in the regional location analyzed and whether the site serves as the Hidden Champion's headquarters (RA13). The regional background of Hidden Champion leadership in terms of biographical origin and current residential location plays an important role as well. A department head of a Chamber of Industry and Commerce in Central Hesse confirmed:

'The executives no longer move to the region. They prefer to drive those 100 kilometers every day instead of moving to the region. Of course, there is the disadvantage that they are not that connected.' (RA8)

Integration in the knowledge application and exploitation subsystem has been identified as stronger for family-owned firms than for those Hidden Champions with other ownership and management models. Management agency plays a much more pronounced role in family-owned firms compared to other ownership models (Chrisman et al. 2014). Additionally, family-owned firms may be better positioned to build and exploit local social capital (Arregle et al. 2007). In this regard, the interview records demonstrate that the long-lasting regional focus of family-owned Hidden Champions conditions the localization of social capital and trust. This, however, may be different for other ownership types of these firms or in cases in which Hidden Champion leadership has been recruited from other regions (RA18). Regarding more generic supplies by contractors such as craftsmanship, firms that are family-owned firms deliberately engage local suppliers regularly due to a sense of regional responsibility. To demonstrate, a Chamber of Industry and Commerce branch manager explained:

\begin{abstract}
'The local roofer does not cover the roof at [Hidden Champion, subsidiary of a large holding]. [Holding] determines this and puts it out for tender. If a firm from the region happens to submit a favorable bid, then they get it. The local family Hidden Champion could not afford to take a roofer from [larger city]. You can't do that in such a small village. There really are differences of cooperation and regional ties.' (RA4)
\end{abstract}

Regional networks among family-owned Hidden Champions and other family SMEs are pertinent. These networks are manifested through various forms, such as business clubs, associations, Chambers of Industry and Commerce, R\&D collaboration, supplier links, and sharing of labor in case of bottlenecks. A regional economic developer from Central Hesse illustrated these networks as follows:

'There is an annual reception here. You notice there how these people flock together. How long they have known each other. You notice the familiarity, the openness with which they deal with each other. It is very nice to experience that. Especially these old business families, they really live for their region.' (RA5) 
In the regional economic landscape, Hidden Champions are portrayed as occupying a special position of being innovative enough to generate intra-regional spillovers to other firms while still being hidden and valuing secrecy (cf. Eder 2019). However, among the firms surveyed, there is substantial heterogeneity regarding awareness of potential local R\&D collaborators (RA26). Larger firms with more than a few hundred employees feature local suppliers that have emerged in their regional vicinity to supply required intermediary products - as in the following example from Lower Saxony:

'We now have a large industrial park, where many smaller suppliers for [Hidden Champion] have emerged. The chemical industry is a big matter here, because [Hidden Champion] is there.' (RA16)

\subsection{Firm-external regional influences}

\section{Integration in RIS subsystems: Knowledge generation and diffusion}

Regional resource availability in terms of research and educational institutions is repeatedly mentioned as determining RIS integration of Hidden Champions, implying that the search for suitable partners is initially conducted locally. However, the lack of awareness of other actors in the knowledge generation and diffusion subsystem is seen as an obstacle. Spatial proximity to larger cities with dense research ecosystems such as Göttingen is emphasized as positively impacting RIS integration (HC27, RA10). Regional research and education institutions are deliberately establishing intra-regional partnerships, also affecting this firm type. In terms of locational requirements and requests for Hidden Champions, the availability of regional research institutions - of research universities and beyond - has gained priority and influences locational decisions such as relocation of corporate units. The director from a Lusatian regional development agency was clear about this:

"It used to go "I need space, I need funding and then the rest comes." Now it is "I need people and I need research". Then comes space, then infrastructure, and at some point "If there was a bit of funding, that would be great." That has completely turned around.' (RA24)

Different approaches in research cooperation by local research universities and universities of applied sciences in rural areas versus big research universities in urban regions also drive patterns of collaboration with Hidden Champions. The CTO from a Hessian slicing systems producer explained it as follows:
'More complex universities view themselves differently - as solution providers: "Okay, you have a problem. We'll internally pull together the departments we need to work with to come up with a solution." And that is basically what we need. We do not get that with the local universities, despite repeated requests.' (HC6)

Secrecy-seeking Hidden Champions form exceptions to integration in the regional knowledge generation and diffusion subsystem, following a logic of secrecy as an exploitation strategy of rural locations (Eder \& Trippl 2019). As a consequence, this applies to integration in the second subsystem of knowledge application and exploitation as well. For the vast majority of these firms, however, co-location of Hidden Champions in related industries is an impetus for new developments in knowledge generation and diffusion subsystems such as co-sponsored professorships (HC19, RA8). As a rationale for these local linkages, the investigated firms frequently cite the necessity of regional visibility to attract qualified labor (HC8/22). Hidden Champions also build alliances with other specialized local firms for strategic purposes, such as requirements for a highly-skilled workforce.

In their regions, firms of this type are described as highly relevant in terms of economic effects - i.e. through business tax, employment, human capital, activities in corporate spatial responsibility, and also due to their suitability for regional marketing through their international business success and innovation. This relevance can be leveraged to realize locational requirements of Hidden Champions, and also includes the initiatives to develop and attract qualified labor described above. Scholars have used the term place leadership for related phenomena (Albers \& Suwala 2021). The CEO from a switchgear-producing Hidden Champion in the Harz foreland illustrated this:

\footnotetext{
'The big advantage is: if we really have problems, then we have a short path here either to the city, to our county, or even to our state government.' (HC26)
}

Regional policies and their institutions, particularly regarding education and training, technology, and innovation, were identified as influencing RIS integration of Hidden Champions. Generally, external policy influences take on various forms of interaction, including infrastructural demands, the search for adequate support programs or for skilled labor, and further administrative matters. Still, self-sufficiency and high degrees of organizational excellence of this firm type have frequently been mentioned, resulting in rare requests for support or assistance addressed to regional actors dedicated to economic development (Simon 2009). Agency of Hidden Champion lead- 
ership, especially for family-owned firms, is important in terms of establishing and maintaining relationships with regional policy institutions as well. This is particularly induced by social capital and trust accumulated over extended periods of time, also considering the generally long tenure of employees in regional administrations. In addition to self-sufficiency, contacts to regional public actors are described as limited to specific requests. A representative from a Lusatian Chamber of Industry and Commerce emphasized the character of self-sufficiency:

\begin{abstract}
'There are businesses that need us as a Chamber of Industry and Commerce, and there are firms that need us less. Hidden Champions can also manage on their own. But if you are active, if you get involved, if you help build networks with your knowledge, then you are a partner for them.' (RA3)
\end{abstract}

The municipal level is consistently commended for its swift response to demands of Hidden Champions, in contrast to greater bureaucracy perceived on larger administrative scales. A direct interest of municipalities in terms of the relevance of the Hidden Champion's business tax base, which is directly allocated to municipalities in Germany, may also influence this. In addition to RIS integration, interviewees have also stressed increased activity by family-owned firms in measures of corporate spatial responsibility such as sponsoring (Albers \& Suwala 2021). In a few instances, family-owned Hidden Champions were active in founding and developing regional development agencies to foster intra-regional innovation cooperation.

\section{Integration in RIS subsystems: Knowledge application and exploitation}

The representatives interviewed generally evaluate regional knowledge application and exploitation linkages of rural Hidden Champions as thin, implying limited localized relations to suppliers, contractors, customers, and other related actors. Often, this is due to geographical proximity to both existing and potential partners (Schäfer \& Meyer 2019). The CTO from a Lower Saxony-based Hidden Champion concluded:

'An ecosystem around me helps to move forward faster. That is the part where we have the hardest time in rural areas. My closest partners are all quite some distance away.' (HC24)

Regional clusters of Hidden Champions in these rural areas form an exception, and particularly those in related industries, e.g. furniture and glass in Leine-Weser or optics, welding, and packaging in Central Hesse (Moßig
2000). Here, the local transfer of employees through attrition and hence of specialized, tacit knowledge constitutes an additional dimension of spillovers. In addition, a history of spin-offs - similar to the corporate evolution of Fairchild Semiconductors in Silicon Valley (Storper et al. 2015) - has been frequently described with regard to these structures. The small town of Haiger in Central Hesse is an example of this, as the CEO of a welding machine Hidden Champion illustrated:

\begin{abstract}
'Our small town is already a special industrial location. Look at all those firms that have emerged, grown, and become large in this small place! [...] That motivates everybody, and so there are some smaller mechanical engineering firms that are unknown and very successful.' (HC19)
\end{abstract}

These particular regions feature a high density of this firm type and other manufacturing SMEs in specific industries despite being classified as rural, leading to regionalized supplier networks. Factors such as regional culture and the promotion of an atmosphere of networking and exchange amplify this. If they exist, Hidden Champions are reported to deliberately support local startups, for instance through engaging them as suppliers or R\&D collaborators. Still, they are described as having high requirements for their suppliers and as valuing good-quality products more highly than regionally sourced intermediate products that do not completely fulfill requirements (Venohr \& Meyer 2007). To compensate for resource constraints and to remain focused on their own technological specialization, Hidden Champions in rural areas report contracting with external (and predominantly extra-regional) service providers such as software and consulting firms as suppliers. Additionally, many have mentioned the potential for rural areas due to the transforming nature of $\mathrm{R} \& \mathrm{D}$ collaboration through digitalization. The CFO of a large seed production Hidden Champion assessed the opportunities induced by digitalization in the following way:

'How do I get knowledge into rural areas? How do I get resources and talent into rural areas? How can I exchange expertise remotely? Of course, digitalization quickly opens up completely different possibilities and completely different exchanges and workflows.' (HC27)

\section{Summary and discussion}

This article has examined the integration of Hidden Champions in rural RIS in Germany and the influence of firm-internal and firm-external regional characteristics on rural RIS integration. The paper has developed the proposition 
that firms of this type are not strongly integrated in rural RIS due to their international sales focus and technological specialization, and posed the following research question: What influences the integration of Hidden Champions in rural regional innovation systems? A RIS framework of two subsystems (knowledge generation and diffusion, and knowledge application and exploitation) was applied to approximate rural RIS integration.

It was found that integration in rural RIS is heterogeneous for Hidden Champions in Germany. The important firm-internal influences identified are ownership structure, firm size, and the organizational status. Regarding ownership, Hidden Champions that are family businesses are on average more integrated in rural RIS than other ownership and leadership types, but vary significantly potentially due to the increased importance of managerial agency and differences in regional social capital. Firms of this type that are subsidiaries of larger corporations, and particularly international ones, display lower integration in RIS - similar to findings on MNEs (Kramer \& Diez 2012). The size of these firms was negatively associated with integration in RIS. There is a crucial distinction to be made between the size of the firm's regional location and the overall firm size in cases of Hidden Champions with multiple locations.

For firm-external regional influences, location and urbanization economies are important dimensions. Greater resource availability in terms of qualified labor and relevant institutions for knowledge generation and application was positively associated with RIS integration for Hidden Champions. A regional knowledge base that is cognitively proximate to the Hidden Champion's technological focus, such as for optics, welding, and packaging in Central Hesse, as well as long-established industrial traditions and an appropriately trained workforce increase rural RIS integration of these firms. Industry, technological focus, degree of peripherality, and characteristics of technology and innovation policy do not play an important role in rural RIS integration of Hidden Champions, according to the actors interviewed.

Additional insight into firm-internal and firm-external dimensions contributes to the debate on influences on rural RIS integration of Hidden Champions. This special firm type has not yet been examined regarding their RIS integration. Here, existing insights into other firm types such as SMEs, MNEs, and family businesses are thus enriched. As rural areas offer challenging conditions for innovation, this paper provides a valuable analysis of highly innovative firms with global market leadership located in this regional context. It could be shown that depending on influencing factors - a significant share of these firms are integrated in rural RIS, contradicting dichotomies between "rural entrepreneurship and entrepreneurship in the rural" (Korsgaardet et al. 2015). Furthermore, this study answers the call for cross-fertilization between economic geography and family business studies (Basco \& Suwala 2020). Here, the existing research focus on the comparative performance of family vs. non-family leadership concerning their home-region focus has been extended (Banalieva \& Eddleston 2011). This has been achieved by limiting the sample to firms with a consistently low home-region focus due to their disproportionately high export shares.

The present findings offer several implications for regional policymakers in rural areas. Facing the relatively low regional integration of this firm type in defiance of their general preference for intra-regional collaboration, attempts to support these rural RIS in enhancing localized learning can be fruitful. Actor-based policies should be at the center of such approaches. Large Hidden Champions have the capacity to be additionally relevant in fostering cluster development in rural areas through their role as anchor firms. Reinforcing and amplifying spillovers and other externalities from them as highly innovative firms to their regional context can strengthen the region at large, countering the metaphor of an anchor tenant without a mall, to paraphrase Agrawal \& Cockburn (2003). In light of increased interest in place-based innovation policies (Grillitsch \& Asheim 2018) and acknowledging the recent launch of the German funding system for structurally weak regions (Gesamtdeutsches Fördersystem), a stronger integration in rural RIS of Hidden Champions as highly innovative firms has potential to contribute to these goals. From a regional development perspective, strengthening family-owned firm structures - particularly concerning firm successions - can contribute to the continued regional integration of this firm type and other businesses. Additionally, the lack of awareness of many Hidden Champions concerning potential regional innovation partners can be improved through better dissemination of information.

Some limitations of the study need to be discussed. It remains unclear how RIS integration of Hidden Champions compares with other SMEs in rural areas. This, however, is beyond the scope of this study due to the research design focusing on this firm type. Limiting the study to four rural regions and their specific economic base of these firms could hinder the generalization of findings in a broader context (Bathelt \& Li 2020). The emphasis of regional characteristics could then underestimate the agency and impact of individual actors, such as Hidden Champions and their management in this context (Bathelt \& Glückler 
2018). The research field of management geography could provide a platform to further analyze the impact of managerial decision-making in the realm of RIS integration (Suwala \& Schlunze 2019). Additionally, the segmentation in subsystems can obliterate recent insights into boundary-spanning activities within RIS (Kerry \& Danson 2016).

The results provide a fruitful base for extended research. Firstly, rural RIS integration of Hidden Champions should be compared with other firm types. Existing research examining the integration of specific types such as family-owned firms does not distinguish the regional context. Secondly, additional research on the relationship of digitalization-related behavior and regional integration of these firms can be insightful in exploring this connection. Thirdly, further studies on the effect of family business successions as well as mergers and acquisitions on regional integration of Hidden Champions may prove relevant in establishing the influence of firm-internal factors such as ownership structure (Lenz \& Glückler 2021). Fourthly, while this paper has focused on the integration of this firm type in rural RIS and their subsystems, additional insights on relations between these firms and civil society and on various regional contributions of Hidden Champions and their importance for their home region, such as economic and intangible effects, may enrich the understanding of the relevance of this firm type for rural areas.

Acknowledgments: This study has been funded by the German Federal Ministry of Food and Agriculture (BMEL) (grant number 2820FD007A). The funding source had no involvement in the research, writing, and submission process. The author would like to thank the editor Harald Bathelt, two anonymous reviewers, Ingo Liefner, Lisa Zirbes, and Leon Worbs for valuable comments and suggestions.

\section{References}

Agrawal, A. \& Cockburn, I. (2003) The anchor tenant hypothesis: exploring the role of large, local, R\&D-intensive firms in regional innovation systems. International Journal of Industrial Organization, 21(9): 1227-1253. https://doi.org/10.1016/ s0167-7187(03)00081-x

Al-Laham, A. \& Souitaris, V. (2008) Network embeddedness and new-venture internationalization: Analyzing international linkages in the German biotech industry. Journal of Business Venturing, 23(5): 567-586.

Albers, H. H. \& Suwala, L. (2021) Place leadership and corporate spatial responsibilities. In: Sotarauta, M. \& Beer,A. (eds) Handbook on City and Regional Leadership (pp. 108-130). London: Edward Elgar Publishing. https://doi. org $/ 10.4337 / 9781788979689.0001$

Arndt, O. \& Sternberg, R. (2000) Do manufacturing firms profit from intraregional innovation linkages? An empirical based answer. European Planning Studies, 8(4): 465-485.

Arregle, J. L., Hitt, M. A., Sirmon, D. G. \& Very, P. (2007) The development of organizational social capital: Attributes of family firms. Journal of Management Studies, (44)1: 73-95. https://doi.org/10.1111/j.1467-6486.2007.00665.x

Asheim, B. T. \& Isaksen, A. (1997) Location, agglomeration and innovation: Towards regional innovation systems in Norway? European Planning Studies, (5)3: 299-330. https://doi. org/10.1080/09654319708720402

Asheim, B. T. \& Isaksen, A. (2002) Regional innovation systems: the integration of local 'sticky'and global 'ubiquitous' knowledge. The Journal of Technology Transfer, 27(1): 77-86.

Asheim, B. T. \& Coenen, L. (2005) Knowledge bases and regional innovation systems: Comparing Nordic clusters. Research Policy, 34(8): 1173-1190.

Autio, E. (1998) Evaluation of RTD in regional systems of innovation. European Planning Studies, (6)2: 131-140. https://doi. org/10.1080/09654319808720451

Autio, E., Kenney, M., Mustar, P., Siegel, D. \& Wright, M. (2014) Entrepreneurial innovation: The importance of context. Research Policy, (43)7: 1097-1108. https://doi.org/10.1016/j. respol.2014.01.015

Banalieva, E. R. \& Eddleston, K. A. (2011) Home-region focus and performance of family firms: The role of family vs non-family leaders. Journal of International Business Studies, 42(8): 1060-1072.

Basco, R. (2015) Family business and regional development-A theoretical model of regional familiness. Journal of Family Business Strategy, (6)4: 259-271. https://doi.org/10.1016/j. jfbs.2015.04.004

Basco, R. \& Suwala, L. (2020) Spatial familiness: a bridge between family business and economic geography. In: Calabrò, A. (eds) A Research Agenda for Family Business (pp. 185-202). London: Edward Elgar Publishing. https://doi. org $/ 10.4337 / 9781788974073.00017$

Basco, R., Stough, R. \& Suwala, L. (2021) Family business and regional development. London: Routledge. https://doi. org $/ 10.4324 / 9780429058097$

Bathelt, H. \& Henn, S. (2017) National and regional innovation systems. In: Bathelt, H., Cohendet, P., Henn, S., \& Simon, L. (eds.) The Elgar companion to innovation and knowledge creation (pp. 457-471). London: Edward Elgar Publishing. https://doi.org/10.4337/9781782548522.00038

Bathelt, H. \& Glückler, J. (2018) Relational research design in economic geography. In: Clark, G. L., Feldman, M. P., Gertler, M. S., \& Wójcik, D. (eds) The New Oxford Handbook of Economic Geography (pp. 179-195). Oxford: Oxford University Press. https://doi.org/10.1093/oxfordhb/9780198755609.013.46

Bathelt, H. \& Li, P. (2020) Building Better Methods in Economic Geography. Zeitschrift für Wirtschaftsgeographie, (64)3: 103-108. https://doi.org/10.1515/zfw-2020-0014

Baù, M., Chirico, F., Pittino, D., Backman, M. \& Klaesson, J. (2019) Roots to grow: Family firms and local embeddedness in rural and urban contexts. Entrepreneurship Theory and Practice, (43)2: 360-385. https://doi.org/10.1177/1042258718796089 
Belso-Martínez, J. A., Díez-Vial, I., López-Sánchez, M. J. \& Sánchez, M. D. (2021) How can R\&D programs induce unplanned R\&D collaborative networks in clusters?. Zeitschrift für Wirtschaftsgeographie. Advance online publication. https://doi. org/10.1515/zfw-2021-0001

Bird, M. \& Wennberg, K. (2014) Regional influences on the prevalence of family versus non-family start-ups. Journal of Business Venturing, (29)3: 421-436. https://doi.org/10.1016/ j.jbusvent.2013.06.004

Block, J. \& Spiegel, F. (2011) Family firms and regional innovation activity: Evidence from the German Mittelstand. MPRA. https:// doi.org/10.2139/ssrn.1745362

Bodner, J., \& Capron, L. (2018) Post-merger integration. Journal of Organization Design, 7(1): 1-20. https://doi.org/10.1186/ s41469-018-0027-4

Boschma, R. \& Frenken, K. (2011) The emerging empirics of evolutionary economic geography. Journal of Economic Geography, (11)2: 295-307. https://doi.org/10.1093/jeg/ lbq053

Branstetter, L. (2006) Is foreign direct investment a channel of knowledge spillovers? Evidence from Japan's FDI in the United States. Journal of International Economics, 68(2): 325-344.

Bürcher, S. (2017) Regional engagement of locally anchored firms and its influence on socio-economic development in two peripheral regions over time. Entrepreneurship \& Regional Development, 29(7-8): 692-714. https://doi.org/10.1080/089 85626.2017.1330903

Capello, R. (2014) Proximity and regional innovation processes: is there space for new reflections?. In: Torre, A. \& Wallet, F. (eds) Regional development and proximity relations (pp. 163-194) London: Edward Elgar.

Capello, R. (2020) Proximity and Regional Competitiveness. Scienze Regionali, 19(3): 373-394.

Chrisman, J. J., Memili, E. \& Misra, K. (2014) Nonfamily managers, family firms, and the winner's curse: The influence of noneconomic goals and bounded rationality. Entrepreneurship Theory and Practice, (38)55: 1-25. https://doi.org/10.1111/ etap.12014

Christopherson, S. \& Clark, J. (2007) Power in firm networks: What it means for regional innovation systems. Regional Studies, 41(9): 1223-1236.

Coe, N. M., Hess, M., Yeung, H. W. C., Dicken, P. \& Henderson, J. (2004) 'Globalizing' regional development: a global production networks perspective. Transactions of the Institute of British Geographers, 29(4): 468-484.

Cooke, P. (2002) Regional innovation systems: general findings and some new evidence from biotechnology clusters. The Journal of Technology Transfer, (27)1: 133-145. https://doi. org/10.1023/a:1013160923450

Cooke, P., Heidenreich, M. \& Braczyk. H. (eds) (2004) Regional innovation systems. London: Routledge

Cooke, P., Clifton, N. \& Oleaga, M. (2005) Social capital, firm embeddedness and regional development. Regional Studies, 39(8): 1065-1077. https://doi. org/10.1080/00343400500328065

Cooke, P., De Laurentis, C., Tödtling, F. \& Trippl, M (eds) (2007) Regional knowledge economies: markets, clusters and innovation. London: Edward Elgar Publishing. https://doi. org/10.4337/9781847206930
Davidsson, P., Delmar, F. \& Wiklund, J. (2006) Conceptual and empirical challenges in the study of firm growth. Entrepreneurship and the Growth of Firms, (1)1: 39-61. https://doi. org $/ 10.4337 / 9781781009949.00010$

Doloreux, D. (2003) Regional innovation systems in the periphery: The case of the Beauce in Québec (Canada). International Journal of Innovation Management, (7)1: 67-94. https://doi. org/10.1142/s1363919603000738

Doloreux, D. \& Dionne, S. (2008) Is regional innovation system development possible in peripheral regions? Some evidence from the case of La Pocatière, Canada. Entrepreneurship and Regional Development, 20(3): 259-283.

Doloreux, D. \& Porto Gomez, I. (2017) A review of (almost) 20 years of regional innovation systems research. European Planning Studies, 25(3): 371-387. https://doi.org/ 10.1080/09654313.2016.1244516

Doloreux, D., Shearmur, R., Porto-Gomez, I. \& Zabala-Iturriagagoitia, J. M. (2020) DUI and STI innovation modes in the Canadian wine industry: The geography of interaction modes. Growth and Change, 51(3): 890-909. https://doi.org/10.1111/ grow.12385

Eder, J. (2019) Innovation in the periphery: A critical survey and research agenda. International Regional Science Review, 42(2): 119-146.

Eder, J. \& Trippl, M. (2019) Innovation in the periphery: Compensation and exploitation strategies. Growth and Change, (50)4: 1511-1531. https://doi.org/10.1111/grow.12328

Eurostat (2020) Methodology on Rural-Urban Typology (NUTS-2021). Available online at: https://ec.europa.eu/eurostat/web/ rural-development/methodology [Accessed October 18, 2021].

Fritsch, M. \& Wyrwich, M. (2021) Is innovation (increasingly) concentrated in large cities? An international comparison. Research Policy, 50(6): 104237.

Gertler, M. S., Wolfe, D. A. \& Garkut, D. (2000) No place like home? The embeddedness of innovation in a regional economy. Review of International Political Economy, (7)4: 688-718. https://doi.org/10.1080/096922900750034581

Gertler, M. S. (2003) Tacit knowledge and the economic geography of context, or the undefinable tacitness of being (there). Journal of Economic Geography, (3)1: 75-99. https://doi.org/10.1093/ jeg/3.1.75

Gibbs, G. (2018) Analyzing qualitative data. Volume 6 of The SAGE qualitative research kit. Los Angeles: SAGE Publications.

Graebner, M. E., Martin, J. A. \& Roundy, P. (2012) Qualitative data: Cooking without a recipe. Strategic Organization, (10)3: 276-284. https://doi.org/10.1177/1476127012452821

Granovetter, M. S. (1973) The strength of weak ties. American Journal of Sociology, 78(6): 1360-1380. https://doi. org $/ 10.1086 / 225469$

Greenberg, Z., Farja, Y. \& Gimmon, E. (2018) Embeddedness and growth of small businesses in rural regions. Journal of Rural Studies, (62): 174-182. https://doi.org/10.1016/j. jrurstud.2018.07.016

Grillitsch, M. \& Nilsson, M. (2015) Innovation in peripheral regions: Do collaborations compensate for a lack of local knowledge spillovers?. The Annals of Regional Science, 54(1): 299-321. https://doi.org/10.1007/s00168-014-0655-8

Grillitsch, M. \& Asheim, B. (2018) Place-based innovation policy for industrial diversification in regions. European Planning 
Studies, 26(8): 1638-1662. https://doi.org/10.1080/09654313 .2018 .1484892

Halaszovich, T. F. \& Lundan, S. M. (2016) The moderating role of local embeddedness on the performance of foreign and domestic firms in emerging markets. International Business Review, 25(5): 1136-1148. https://doi.org/10.1016/j. ibusrev.2016.02.003

Herb, C. \& Neiberger, C. (2021) Intermediation, Disintermediation und Cybermediäre: Zum Einfluss der Digitalisierung auf Wertschöpfungsketten in der Schuhbranche. Zeitschrift für Wirtschaftsgeographie. Advance online publication. https:// doi.org/10.1515/zfw-2020-0036

Huggins, R. \& Thompson, P. (2015) Entrepreneurship, innovation and regional growth: a network theory. Small Business Economics, 45(1): 103-128. https://doi.org/10.1007/s11187015-9643-3

Oberst, C., Kempermann, H. \& Schröder, C. (2019) Räumliche Entwicklung in Deutschland. In: Hüther, M., Südekum, J., \& Voigtländer, M. (eds) Die Zukunft der Regionen in Deutschland: Zwischen Vielfalt und Gleichwertigkeit (pp. 87-114) Köln: IW. Available online at: https://www.econstor.eu/ handle/10419/215907 [Accessed October 18, 2021].

Isaksen, A. \& Karlsen, J. (2016) Innovation in peripheral regions. In: Shearmur, R., Carrincazeaux, C., \& Doloreux, D. (eds) Handbook on the Geographies of Innovation. London: Edward Elgar, 277-286. https://doi.org/10.4337/9781784710774.00030

Kalantaridis, C. \& Bika, Z. (2006) Local embeddedness and rural entrepreneurship: case-study evidence from Cumbria, England. Environment and Planning A, (38)8: 1561-1579. https://doi.org/10.1068/a3834

Keeble, D., Lawson, C., Smith, H. L., Moore, B. \& Wilkinson, F. (1998) Internationalisation processes, networking and local embeddedness in technology-intensive small firms. Small Business Economics, 11(4): 327-342. https://doi. org/10.1023/a:1007942612220

Kerry, C. \& Danson, M. (2016) Open innovation, Triple Helix and regional innovation systems: Exploring CATAPULT Centres in the UK. Industry and Higher Education, 30(1): 67-78.

Korsgaard, S., Müller, S. \& Tanvig, H. W. (2015) Rural entrepreneurship or entrepreneurship in the rural-between place and space. International Journal of Entrepreneurial Behavior \& Research, 21(1): 5-26.

Kramer, J. P. \& Diez, J. R. (2012) Catching the local buzz by embedding? Empirical insights on the regional embeddedness of multinational enterprises in Germany and the UK. Regional Studies, (46)10: 1303-1317. https://doi.org/10.1080/0034340 4.2011.571240

Küpper, P. (2016) Abgrenzung und Typisierung ländlicher Räume (No. 68). Thünen Working Paper. Available online at: https:// literatur.thuenen.de/digbib_extern/dn057783.pdf [Accessed October 18, 2021].

Lalić, A. B. (2021) Hidden Champions in Dynamically Changing Societies: Critical Success Factors for Market Leadership. Berlin: Springer Nature.

Larsson, S., \& Malmberg, A. (1999) Innovations, competitiveness and local embeddedness: A study of machinery producers in Sweden. Geografiska Annaler: Series B, Human Geography, 81(1): 1-18. https://doi.org/10.1111/1468-0467.00045

Lenz, R. \& Glückler, J. (2021) Same same but different: regional coherence between institutions and policies in family firm succession. European Planning Studies, 29(3): 536-555. https://doi.org/10.1080/09654313.2020.1757041

MacKinnon, D. (2012) Beyond strategic coupling: reassessing the firm-region nexus in global production networks. Journal of Economic Geography, 12(1): 227-245. https://doi.org/10.1093/ jeg/lbr009

Meili, R. \& Shearmur, R. (2019) Diverse diversities - Open innovation in small towns and rural areas. Growth and Change, 50(2): 492-514. https://doi.org/10.1111/grow.12291

Meuser, M. \& Nagel, U. (2009) The expert interview and changes in knowledge production. In: Bogner, A., Littig, B., \& Menz, W. (eds) Interviewing experts (pp. 17-42). London: Palgrave Macmillan.

Meyer, K. E., Mudambi, R. \& Narula, R. (2011) Multinational enterprises and local contexts: The opportunities and challenges of multiple embeddedness. Journal of Management Studies, (48)2: 235-252. https://doi.org/10.1111/j.14676486.2010.00968.x

Miller, D. \& Le Breton-Miller, I. (2020) Family Firms: A Breed of Extremes? Entrepreneurship Theory and Practice. Advance online publication. 1-19. October 2020. https://doi. org/10.1177/1042258720964186

Moulaert, F. \& Sekia, F. (2003) Territorial innovation models: a critical survey. Regional Studies, 37(3): 289-302. https://doi. org $/ 10.1080 / 0034340032000065442$

Moßig, I. (2000) Lokale Spin-off-Gründungen als Ursache räumlicher Branchencluster. Das Beispiel der deutschen Verpackungsmaschinenbau-Industrie. Geographische Zeitschrift, 88(3), 220-233.

Müller, C. (2018) Der Weltmarktführer-Index für die DACH-Region. In: Büchler, J. P. (ed.) Fallstudienkompendium Hidden Champions - Innovationen für den Weltmarkt. Wiesbaden: Springer Gabler (pp- 223-229). https://doi.org/10.1007/978-3658-17829-1_13

Munari, F., Sobrero, M. \& Malipiero, A. (2012) Absorptive capacity and localized spillovers: Focal firms as technological gatekeepers in industrial districts. Industrial and Corporate Change, 21(2): 429-462. https://doi.org/10.1093/icc/dtr053

Pallares-Barbera, M., Tulla, A. F. \& Vera, A. (2004) Spatial loyalty and territorial embeddedness in the multi-sector clustering of the Berguedà region in Catalonia (Spain). Geoforum, 35(5): 635-649. https://doi.org/10.1016/j.geoforum.2004.03.004

Polèse, M. \& Shearmur, R. (2006) Why some regions will decline: A Canadian case study with thoughts on local development strategies. Papers in Regional Science, 85(1): 23-46.

Rammer, C. \& Spielkamp, A. (2015) Hidden champions driven by innovation: Empirische Befunde auf Basis des Mannheimer Innovationspanels. ZEW-Dokumentation, 15. Available at: https://www.zew.de/publikationen/ hidden-champions-driven-by-innovation-empirische-befundeauf-basis-des-mannheimer-innovationspanels [Accessed October 18, 2021].

Reidolf, M. (2016) Knowledge networks and the nature of knowledge relationships of innovative rural SMEs. European Journal of Innovation Management, 19(3): 317-336. doi: 10.1108/EJIM-062015-0043.

Schäfer, S. \& Mayer, H. (2019) Entrepreneurial ecosystems: Founding figures and research frontiers in economic geography. Zeitschrift für Wirtschaftsgeographie, 63(2-4), 55-63. https://doi.org/10.1515/zfw-2019-0008 
Schenkenhofer, J. (2020) Hidden Champions: A review of the literature \& future research avenues. UO Working Papers, (20)6. Available online at: https://www.econstor.eu/ handle/10419/222408 [Accessed October 18, 2021].

Simon, H. (2009) Hidden champions of the twenty-first century: The success strategies of unknown world market leaders. Luxemburg: Springer Science \& Business Media. https://doi. org/10.1007/978-0-387-98147-5

Simon, H. (2018) Hidden Champions-Innovative Speerspitze der Globalisierung. In: Büchler, J. P. (ed.) Fallstudienkompendium Hidden Champions (pp. 3-19). Wiesbaden: Springer Gabler. https://doi.org/10.1007/978-3-658-17829-1_1

Statistisches Bundesamt (2021) Gemeindeverzeichnis - Online. Available online at: https://www.statistikportal.de/de/ gemeindeverzeichnis [Accessed October 18, 2021].

Statistisches Landesamt Baden-Württemberg (2020) Exportquote im Bundesländervergleich. Available online at: https:// www.statistik-bw.de/HandelDienstl/Aussenhandel/AH-XP_ exportquote.jsp [Accessed October 18, 2021].

Sternberg, R. \& Arndt, O. (2001) The firm or the region: what determines the innovation behavior of European firms?. Economic Geography, 77(4): 364-382.

Stiftung Familienunternehmen (2020) Die Bedeutung der Familienunternehmen für ländliche Räume. Beitrag für Wohlstand und Zusammenhalt. Available online at: https://www.familienunternehmen.de/ media/public/pdf/publikationen-studien/studien/ Die-Bedeutung-der-Familienunternehmen-fuerlaendliche-Raeume_Studie_Stiftung-Familienunternehmen.pdf [Accessed October 18, 2021].

Storper, M., Kemeny, T., Makarem, N. \& Osman, T. (2015) The rise and fall of urban economies: Lessons from San Francisco and Los Angeles. Stanford: Stanford University Press.

Streeck, W. (2009) Re-forming capitalism: Institutional change in the German political economy. Oxford: Oxford University Press.
Suwala, L. \& Micek, G. (2018) Beyond clusters? Field configuration and regional platforming: the Aviation Valley initiative in the Polish Podkarpackie region. Cambridge Journal of Regions, Economy and Society, 11(2): 353-372.

Suwala, L. \& Schlunze, R. D. (2019) The stony path of management geography. SIEM Bulletin, 1(1): 1-5.

The Atlantic (2021) Superstar Cities Are in Trouble. Available online at: https://www.theatlantic.com/ideas/archive/2021/02/ remote-work-revolution/617842/ [Accessed October 18, 2021].

Tödtling, F. \& Trippl, M. (2005) One size fits all?: Towards a differentiated regional innovation policy approach. Research Policy, 34(8): 1203-1219. https://doi.org/10.1016/j. respol.2005.01.018

Venohr, B. \& Meyer, K. (2007) The German Miracle Keeps Running: How Germany's Hidden Champions Stay Ahead in the Global Economy. Berlin School of Economics Working Paper, 30(1): 1-33. https://doi.org/10.2139/ssrn.991964

Virkkala, S. (2007) Innovation and networking in peripheral areas - a case study of emergence and change in rural manufacturing. European Planning Studies, 15(4): 511-529. https://doi.org/10.1080/09654310601133948

Voudouris, I., Lioukas, S., Makridakis, S. \& Spanos, Y. (2000) Greek hidden champions: lessons from small, little-known firms in Greece. European Management Journal, 18(6), 663-674. https://doi.org/10.1016/s0263-2373(00)00057-8

Watts, H. D., Wood, A. M. \& Wardle, P. (2006) Owner-managers, clusters and local embeddedness: small firms in the Sheffield (UK) metal-working cluster. Entrepreneurship and Regional Development, 18(3): 185-205. https://doi. org/10.1080/08985620600680141

Wittenstein, D. (2020) Champions of digital transformation? The dynamic capabilities of hidden champions. ZEW Discussion Papers, (20)065: 1-70. https://doi.org/10.2139/ssrn.3736759

Yin, X., Chen, J. \& Li, J. (2019) Rural innovation system: Revitalize the countryside for a sustainable development. Journal of Rural Studies. Advance online publication. https://doi.org/10.1016/j. jrurstud.2019.10.014 


\section{Online Appendix}

Table A.1: Description of interview sample of Hidden Champions

\begin{tabular}{|c|c|c|c|c|c|c|}
\hline ID & Industry & $\begin{array}{l}\text { Firm founda- } \\
\text { tion }\end{array}$ & $\begin{array}{l}\text { Firm revenue } \\
\text { (mill. €) }\end{array}$ & $\begin{array}{l}\text { Employees } \\
\text { (\#) }\end{array}$ & Ownership structure & $\begin{array}{l}\text { Interview dura- } \\
\text { tion (min.) }\end{array}$ \\
\hline $\mathrm{HC} 1$ & Extension spindles and poles & $1990 \mathrm{~s}$ & $\sim 5$ & $\sim 50$ & Family & 85 \\
\hline $\mathrm{HC} 2$ & Wireless controls & $1990 \mathrm{~s}$ & $\sim 50$ & $\sim 180$ & Family & 64 \\
\hline $\mathrm{HC} 3$ & Lithium-ion batteries & $2000 \mathrm{~s}$ & $\sim 90$ & $\sim 1600$ & Holding subsidiary & 51 \\
\hline $\mathrm{HC} 4$ & Water ultrafiltration & $2000 \mathrm{~s}$ & $\mathrm{n} / \mathrm{a}$ & $\sim 140$ & Holding subsidiary & 59 \\
\hline $\mathrm{HC} 5$ & Ladder systems & $1940 \mathrm{~s}$ & $\sim 150$ & $\sim 500$ & Holding subsidiary & 59 \\
\hline $\mathrm{HC6}$ & Slicing systems & $1980 \mathrm{~s}$ & $\sim 250$ & $\sim 1400$ & Family & 56 \\
\hline $\mathrm{HC7}$ & Bowden cables & $2000 \mathrm{~s}$ & $\mathrm{n} / \mathrm{a}$ & $\mathrm{n} / \mathrm{a}$ & Family & 30 \\
\hline $\mathrm{HC} 8$ & Steel construction & 1990s & $\sim 30$ & $\sim 200$ & Family & 35 \\
\hline $\mathrm{HC9}$ & Extraction and filtration & $1990 \mathrm{~s}$ & $\sim 30$ & $\sim 130$ & Family & 55 \\
\hline $\mathrm{HC} 10$ & Electrical safety & $1940 \mathrm{~s}$ & $\sim 150$ & $\sim 900$ & Family & 50 \\
\hline $\mathrm{HC} 11$ & Buffet solutions & $1980 \mathrm{~s}$ & $\sim 5$ & $\sim 20$ & Holding subsidiary & 51 \\
\hline $\mathrm{HC} 12$ & Festive decoration & $1890 \mathrm{~s}$ & $\sim 10$ & $\sim 150$ & Family & 45 \\
\hline $\mathrm{HC} 13$ & $\begin{array}{l}\text { Fine chemistry and fragrance } \\
\text { components }\end{array}$ & $1990 \mathrm{~s}$ & $\sim 15$ & $\sim 50$ & Family & 44 \\
\hline $\mathrm{HC} 14$ & Marine gearboxes & $1870 \mathrm{~s}$ & $\sim 80$ & $\sim 500$ & Foundation & 63 \\
\hline $\mathrm{HC} 15$ & $\begin{array}{l}\text { Digital radio systems and } \\
\text { terminals }\end{array}$ & $1980 \mathrm{~s}$ & $\sim 90$ & $\sim 50$ & Holding subsidiary & 92 \\
\hline $\mathrm{HC} 16$ & Specialized textiles & 1990s & $\sim 40$ & $\sim 150$ & Family & 40 \\
\hline $\mathrm{HC} 17$ & Confectionery process lines & $1920 \mathrm{~s}$ & $\sim 50$ & $\sim 250$ & Holding subsidiary & 49 \\
\hline $\mathrm{HC} 18$ & Foundry technology & $1990 \mathrm{~s}$ & $\mathrm{n} / \mathrm{a}$ & $\sim 30$ & Family & 54 \\
\hline $\mathrm{HC} 19$ & Welding machines & $1910 \mathrm{~s}$ & $\sim 120$ & $\sim 500$ & Holding subsidiary & 57 \\
\hline $\mathrm{HC} 20$ & Office furniture & $1900 \mathrm{~s}$ & $\sim 80$ & $\sim 600$ & Family & 57 \\
\hline $\mathrm{HC} 21$ & Spark extinguishers & $1910 \mathrm{~s}$ & $\sim 90$ & $\sim 650$ & Family & 74 \\
\hline $\mathrm{HC} 22$ & Central heating products & $1920 \mathrm{~s}$ & $\sim 600$ & $\sim 3700$ & Foundation & 60 \\
\hline $\mathrm{HC} 23$ & Welding torches & $1940 \mathrm{~s}$ & $\sim 300$ & $\sim 2200$ & Private equity & 62 \\
\hline $\mathrm{HC} 24$ & Powertrain technology & $1940 \mathrm{~s}$ & $\sim 800$ & $\sim 4000$ & Foundation & 63 \\
\hline $\mathrm{HC} 25$ & Software engineering & $1990 s$ & $\sim 10$ & $\sim 80$ & Family & 69 \\
\hline $\mathrm{HC} 26$ & Switchgear & $1990 \mathrm{~s}$ & $\sim 60$ & $\sim 200$ & Holding subsidiary & 46 \\
\hline $\mathrm{HC} 27$ & Seed production & $1850 \mathrm{~s}$ & $\sim 1700$ & $\sim 5700$ & Public & 50 \\
\hline $\mathrm{HC} 28$ & Float glass & $2000 \mathrm{~s}$ & $\sim 300$ & $\sim 250$ & Holding subsidiary & 65 \\
\hline Averag & & & 195 & 890 & $n / a$ & 57 \\
\hline
\end{tabular}

Source for firm data: Bureau van Dijk and desk research; latest data available for revenue and employees. 
Table A.2: Description of interview sample of regional actors

\begin{tabular}{|c|c|c|c|}
\hline ID & Type of regional actor & Region & Interview duration (min.) \\
\hline RA1 & Regional economic development agency & Leine-Weser & 56 \\
\hline RA2 & Regional economic development agency & Harz foreland & 40 \\
\hline RA3 & Chamber of Industry and Commerce & Lausitz/Lusatia & 60 \\
\hline RA4 & Chamber of Industry and Commerce & Lausitz/Lusatia & 60 \\
\hline RA5 & Regional economic development agency & Central Hesse & 63 \\
\hline RA6 & Chamber of Industry and Commerce & Harz foreland & 60 \\
\hline RA7 & Regional economic development agency & Lausitz/Lusatia & 60 \\
\hline RA8 & Chamber of Industry and Commerce & Central Hesse & 63 \\
\hline RA9 & Regional economic development agency & Leine-Weser & 50 \\
\hline RA10 & Regional innovation agency & Leine-Weser & 65 \\
\hline RA11 & Regional economic development agency & Central Hesse & 45 \\
\hline RA12 & Employers association & Lausitz/Lusatia & 75 \\
\hline RA13 & Technology transfer agency & Harz foreland & 60 \\
\hline RA14 & Regional economic development agency & Central Hesse & 60 \\
\hline RA15 & Chamber of Industry and Commerce & Lausitz/Lusatia & 60 \\
\hline RA16 & Regional innovation agency & Leine-Weser & 64 \\
\hline RA17 & Employers association & Central Hesse & 65 \\
\hline RA18 & Mayor & Central Hesse & 50 \\
\hline RA19 & Mayor & Leine-Weser & 48 \\
\hline RA20 & Regional economic development agency & Harz foreland & 30 \\
\hline RA21 & State economic development agency & Central Hesse & 75 \\
\hline RA22 & Regional economic development agency & Leine-Weser & 60 \\
\hline RA23 & Regional economic development agency & Central Hesse & 50 \\
\hline RA24 & Regional economic development agency & Lausitz/Lusatia & 70 \\
\hline RA25 & Regional economic development agency & Lausitz/Lusatia & 60 \\
\hline RA26 & Chamber of Industry and Commerce & Leine-Weser & 50 \\
\hline RA27 & Regional location marketing agency & Harz foreland & 25 \\
\hline RA28 & Chamber of Industry and Commerce & Lausitz/Lusatia & 60 \\
\hline RA29 & Chamber of Industry and Commerce & Harz foreland & 60 \\
\hline \multicolumn{3}{|c|}{ Average: } & 57 \\
\hline
\end{tabular}

Source: Own elaboration. 
Table A.3: Identified influencing factors of RIS integration of Hidden Champions

\begin{tabular}{lll}
\hline Influencing & $\begin{array}{l}\text { Number } \\
\text { of cases }\end{array}$ & Selected interview quotes \\
factors &
\end{tabular}

Firm-internal characteristics

\begin{tabular}{ll}
\hline Ownership $39 \quad-\quad$ 'Yes, they [subsidiaries of larger corporations] may be Hidden Champions, but they are all externally deter- \\
structure \\
mined. [...] We have hardly had any contact with most of the firms in the last five years or so, because head- \\
quarters are just far away in Brazil or Mexico.' (RA13) \\
- 'The innovative firms, the Hidden Champions, most of them feel a regional connection. But: they are also \\
family-run. You can say: all those that are not family-run and were not founded in the region have little con- \\
nection to the region.' (RA29) \\
$-\quad$ 'The local roofer does not cover the roof at [Hidden Champion, subsidiary of a large holding]. [Holding] deter- \\
mines this and puts it out for tender, and if a firm from the region happens to submit a favorable bid, then \\
they get it. The local family Hidden Champion could not afford to take a roofer from [larger city]. You can't do \\
that in such a small village. There really are differences of cooperation and regional ties.' (RA4) \\
- 'There is an annual reception here. You notice there how these people flock together. How long they have \\
known each other. You notice the familiarity, the openness with which they deal with each other. It is very \\
nice to experience that. Especially these old business families, they really live for their region.' (RA5) \\
- 'We have had the experience that when firms are sold, this culture is quickly lost. If the managing directors \\
no longer sit locally, but somewhere in Hamburg ... We have a window manufacturer which was taken over by \\
a Hamburg firm. Within two years, almost the entire workforce had resigned and left.' (RA18) \\
- 'Strategic cooperation on such a long-term basis is still a rarity. We once had a company that conducted \\
[regional strategic cooperation] very strongly. But the firm has now been sold to the Bosch Group because \\
the owner was childless. [...] Bosch is a large corporation. It has its own dynamics. None of us can get in \\
touch with them.' (RA5)
\end{tabular}

Firm size $\quad 34 \quad$ - 'We are simply too big for that. [...] If we want funding, we have to go to the state or the federal government.'
(HC14)

- 'The larger Hidden Champions, they have isolated themselves from the region quite a bit.' (RA13)

- 'We now have a larger industrial park, where many smaller suppliers for [Hidden Champion] have emerged. This whole chemical industry is a big matter here, because [Hidden Champion] is there.' (RA16)

- 'The bigger the firms are - they are now part of the [holding] as they have been bought - the less they are anchored in the region.' (RA13)

- '[Hidden Champions], that's a very small firm. I didn’t even know the firm before I became mayor, honestly. [...] They do not radiate that strongly into our town and region.' (RA18)

- 'Of course, the firms also have relationships beyond the state borders. Especially the very large Hidden Champions are then probably even better networked with ministries that are responsible for any approvals than perhaps our small district itself.' (RA27)

Organizational 26 status
- 'And I actually don't even know if they are all still paying their business taxes here locally. The headquarters may not even be here anymore. We have had hardly any contact with most of these firms in the last five, six years.' (RA13)

- 'When in Quebec, or wherever, the decision is made to close a plant, it's emotionless. If they are based here, if the enterprise has been part of the municipality for decades, it is not as simple to close down, it is a more emotional process.' (RA24)

- 'The large Hidden Champions usually have a central purchasing department at another headquarters. [...] If you have small Hidden Champions, many of course buy in the region.' (RA27)

- 'It was also a way to make ourselves known locally again. Of course, the people in Mexico don't even know that there is a university in Wernigerode. That's just the way it is, yes. [...] The bigger the firms become and the more they emerge as world market leaders, they become more interesting for foreign firms, for large corporations. Be it Bohai from China or Nemak from Mexico. And then they get bought out and are a bit lost in the decision-making structure for us. The impact in the region is sometimes lost as well, because the people who make the decisions are sitting far away.' (RA13)

- 'These firms mainly operate externally at their headquarters' location.' (RA6) 


\begin{tabular}{lll}
\hline $\begin{array}{l}\text { Influencing } \\
\text { factors }\end{array}$ & $\begin{array}{l}\text { Number } \\
\text { of cases }\end{array}$ & Selected interview quotes \\
\hline
\end{tabular}

Firm-internal characteristics

Firm-external regional characteristics

Location $\quad 31 \quad-$ 'An ecosystem around me helps to move forward faster. That is the part where we have the hardest time in

(or milieu) rural areas. My closest partners are all quite some distance away.' (HC24)

economies

- 'The region in which we are located, l'll just say that now, doesn't really matter. We don't have our customers here in the region, we have them somewhere else, because the hotels we supply are not in the rural areas.' (HC11)

- 'The customers are supra-regional, and we only have a connection to [town] directly, because the firm location is here, not to the place per se.' (HC8)

- 'Our small town is already a special industrial location. Look at all those firms that have emerged, grown, and become large in this small place! [...] That motivates everybody, and so there are some smaller mechanical engineering firms that are unknown and very successful.' (HC19)

- 'It is for reasons of specialization that Hidden Champions look for research cooperation in other regions if they really need a highly specialized university. For instance, a Fraunhofer Institute is being established here - an institute for insect biotechnology.' (RA5)

- 'If I needed a supplier who can deliver this part to me in time and quality for the price, then of course digitization is great. So if it's worldwide, someone with whom I wouldn't necessarily have to meet, with whom I don't necessarily have to sit at a table, but with whom I simply negotiate the terms and conditions and he has to assure me of timely delivery, then everything is good. I think that these are different relationship levels.' (RA4)

- 'They have actually built up very good relationships with local firms in this area and don't always look at whether it's cheaper to have this developed in China, India, or whatever. Instead, if local partners are called, they'll be there in a quarter of an hour and can also fix something on site. So, for the most part, it has remained regional.' (RA25)

- 'I know that people help each other out when it comes to skilled workers. So I know for example - I also find this quite exciting - that [Hidden Champion] also sends trainees over to its competitor in Eisleben when there's a need.' (RA27)

- 'There is also the issue of networking among the firms. You have to travel further to find firms that are active in a similar field or with whom you can cooperate [as a Hidden Champion], where you can exchange information, etc. That's a huge problem.' (RA12)

- 'The Hidden Champions live from the fact that they have a short route, short communication channels to their suppliers in the region, who implement this directly. [...] We have a large proportion of metal processors and plastics processors here. The larger Hidden Champions are then Tier 2 or Tier 1 suppliers for the automotive industry. The entire value chain is represented and there is an intensive exchange and an intensive economic cooperation between these firms.' (RA8)

Urbanization $29 \quad-$ - It used to go "I need space, I need funding and then the rest comes." Now it is "I need people and I need economies research". Then comes space, then infrastructure, and at some point "If there was a bit of funding, that would be great." That has completely turned around.' (RA24)

- 'More complex universities see themselves differently - as solution providers: "Okay, you have a problem. We'll internally pull together the departments we need to work with to come up with a solution." And that is basically what we need. We do not get that with the local universities despite repeated requests.' (HC6)

- 'The big advantage is: if we really have problems, then we have a short path here either to the city, to our county, or even to our state government.' (HC26)

- 'There are businesses that need us as a Chamber of Industry and Commerce. And there are firms that need us less. Hidden Champions can also manage on their own. But if you are active, if you get involved, if you help build networks with your knowledge, then you are a partner for them.' (RA3)

- 'We also have a technical university. It was two years ago that firms from the optics industry joined forces and created an optics professorship because they needed special experts. And these are mainly local Hidden Champions, because an optics cluster is very present here.' (RA7)

- 'That type of cooperation is sought after. [...] However, it is not that much driven by the desire to enrich the region, but rather by the necessity to attract the attention of young skilled workers.' (RA6)

- 'We don't have a university in the district. But the proximity to Dresden is a great advantage. So with the TU, with the HTW, with the Fraunhofer Institutes, there are quite a few relationships with Hidden Champions.' (RA25).

- 'You have to make sure that you try to keep vocational school classes for certain professions in the region, that's always an issue, for training cooperation.' (RA7) 